\title{
GOSPODARKA O OBIEGU ZAMKNIĘTYM - WYZWANIA DLA PRZEDSIĘBIORSTW
}

\author{
CIRCULAR ECONOMY - CHALLENGES FOR ENTERPRISES
}

\begin{abstract}
The circular economy seeks to separate economic growth from resource use and environmental impact. For enterprises, it is a source of both potential benefits and serious challenges. The aim of the article is to identify the challenges that companies implementing the assumptions of this concept must face. The business models and strategies characteristics of a circular economy were also presented. This article is theoretical.
\end{abstract}

Keywords: circular economy, environment, enterprises

JEL classification: M14, O44, Q50

\section{Wprowadzenie}

Pomnażanie kapitału spowodowane zwiększeniem masy wykorzystywanych zasobów oraz ich szybszy obieg w procesie produkcji stanowią istotę współczesnego systemu gospodarczego. Warunkiem funkcjonowania takiego systemu jest wchłanianie nowych obszarów, poszukiwanie nowych źródeł energii, surowców, zasobów ludzkich czy pobudzanie postępu technologicznego. Odkąd światowa gospodarka osiągnęła poziom rozwoju, który może stwarzać znaczące zagrożenie dla środowiska, zaczęto zwracać większą uwagę na barierę ekologiczną ${ }^{1}$.

* Politechnika Częstochowska; kamilkwiecien94a@gmail.com

${ }^{1}$ M. Rutkowska-Podołowska, Ł. Popławski, Współczesny kapitalizm a ochrona środowiska, „Studia i Prace Wydziału Nauk Ekonomicznych i Zarządzania Uniwersytetu Szczecińskiego” 2015, t. 2 , nr 41, s. 77. 
Aby osiągnąć harmonię w relacjach człowieka ze środowiskiem naturalnym, niezbędne jest zrozumienie rządzących nimi zależności oraz odrzucenie egoistycznej postawy opartej wyłącznie na własnych krótkoterminowych korzyściach. Ponadto istotne są zmiany w sposobie życia i produkcji².

Okres globalnej industrializacji charakteryzował się rosnącą efektywnością wykorzystania materiałów i energii. Od początku XX wieku można było zaobserwować znaczący spadek energochłonności $(0,68 \%$ rocznie) oraz materiałochłonności (nawet $1 \%$ rocznie). Nie przyczyniło się to jednak do redukcji zużycia ${ }^{3}$. Wyższy poziom PKB per capita wiąże się zwykle z większym zużyciem materiałów w przeliczeniu na jednego mieszkańca. W ujęciu historycznym jednoprocentowy wzrost PKB szedł w parze ze wzrostem zużycia zasobów średnio o 0,4\%. Zwraca się uwagę, że wzrost gospodarczy, postrzegany dotąd jako uniwersalny środek rozwiązujący wszelkie trudności, staje się obecnie źródłem największych światowych problemów ${ }^{4}$. Imperatyw wzrostu determinuje model gospodarczy, który sprowadza się do nieustannego zwiększania tempa i wolumenu produkcji oraz konsumpcji. Prowadzi to do szeregu negatywnych konsekwencji, m.in. do wyczerpywania się naturalnych zasobów, zmniejszenia bioróżnorodności czy generowania rosnących strumieni odpadów ${ }^{5}$. Warto zaznaczyć, że rozwój gospodarczy jest pożądany i nie można zaakceptować jego zatrzymania czy cofnięcia, jednak dotychczasowe założenia dotyczące wzrostu nie odpowiadają złożonym potrzebom współczesnych społeczeństw, środowiska oraz gospodarki ${ }^{6}$. Alternatywę dla liniowego modelu gospodarki, który opiera się na zasadzie take-make-waste (weź, zrób, wyrzuć), stanowi gospodarka o obiegu zamkniętym ${ }^{7}$. Jej celem jest oddzielenie wzrostu gospodarczego od zużycia zasobów oraz wpływu na środowisko naturalne. $\mathrm{W}$ efekcie rozwój ekonomiczny ma odbywać się w warunkach zarówno zmniejszającego się wykorzystania zasobów, jak i ograniczonego oddziaływania na środowisko ${ }^{8}$.

2 J. Mao, Ch. Liu, Y. Pei, L. Xu, Circular economy and sustainable development enterprises, Springer Nature, Singapore 2018, s. 18.

${ }^{3}$ F. Krausmann, S. Gingrich, N. Eisenmenger, K.H. Erb, H. Haberl, M. Fischer-Kowalski, Growth in global material use, GDP and population during the 20th century, „Ecological Economics" 2009, Vol. 68, No. 10, s. 2702.

${ }^{4}$ P. Lacy, J. Rutqvist, Waste to wealth. Creating advantage in a circulareconomy, Palgrave Macmillan, New York 2015, s. 3-5.

${ }^{5}$ E. Rokicka, W. Woźniak, W kierunku zrównoważonego rozwoju. Koncepcje, interpretacje, konteksty, Katedra Socjologii Ogólnej, Wydział Ekonomiczno-Socjologiczny, Uniwersytet Łódzki, Łódź 2016, s. 149.

${ }^{6}$ P. Lacy, J. Rutqvist, Waste to wealth ..., s. 4.

${ }^{7}$ E. Rokicka, W. Woźniak, W kierunku zrównoważonego rozwoju..., s. 149.

${ }^{8}$ R.C. Brears, Natural resource management and the circular economy, Palgrave Macmillan, New York 2018, s. 13. 


\section{Gospodarka o obiegu zamkniętym - istota koncepcji}

W literaturze przedmiotu spotyka się różne definicje gospodarki o obiegu zamkniętym $(\mathrm{GOZ})^{9}$. Jedną z najczęściej przywoływanych jest definicja znajdująca się w Komunikacie Komisji Europejskiej pt. Zamknięcie obiegu - plan działania UE dotyczacy gospodarki o obiegu zamkniętym. Zgodnie z nią jest to gospodarka, w której „wartość produktów, materiałów i zasobów [...] jest utrzymywana tak długo, jak to możliwe, a wytwarzanie odpadów ograniczone do minimum"10. Komisja zaznaczyła również, że przejście na gospodarkę obiegu zamkniętego w znacznym stopniu przyczynia się do budowy gospodarki, którą można określić jako zrównoważoną, niskoemisyjną, zasobooszczędną oraz konkurencyjną ${ }^{11}$.

Główne założenia GOZ skupiają się na rozwiązaniu konfliktu wiążącego się obecnie z nadmierną konsumpcją zasobów ${ }^{12}$. W koncepcji tej wykluczone zostaje pojęcie „końca życia” produktu bądź usługi. Nacisk kładzie się na ponowne użycie, nieustanne odbudowywanie oraz wykorzystywanie tego, co odnawialne. Gospodarki obiegu zamkniętego nie należy jednak postrzegać jako koncepcji nastawionej wyłącznie na redukcję ilości generowanych odpadów i ich odpowiednie zagospodarowanie ${ }^{13}$. W raporcie autorstwa firmy doradczej Deloitte stwierdzono, że GOZ „reprezentuje strategię rozwoju, która umożliwia wzrost gospodarczy przy jednoczesnej optymalizacji zużycia zasobów, głęboko przekształca schematy łańcuchów produkcji i konsumpcji oraz projektuje na nowo systemy przemysłowe" 14 .

U podstaw koncepcji gospodarki cyrkulacyjnej leży założenie, że stanowi ona nieustający cykl rozwoju. Zachowuje i wzbogaca kapitał naturalny, jednocześnie optymalizując zyski surowcowe i minimalizując ryzyko systemowe przez efektywne zarządzanie strumieniami materiałów. Wyróżnić można pięć fundamentalnych cech gospodarki obiegu zamkniętego ${ }^{15}$ :

9 Powszechnie używa się także pojęć „gospodarka obiegu zamkniętego” czy „gospodarka cyrkulacyjna".

${ }^{10}$ Komisja Europejska, Zamknięcie obiegu - plan działań UE dotyczacy gospodarki o obiegu zamkniętym, Komunikat Komisji do Parlamentu Europejskiego, Rady, Europejskiego Komitetu Ekonomiczno-Społecznego i Komitetu Regionów, COM(2015) 614 final, Bruksela 2015, s. 2.

${ }^{11}$ Ibidem.

12 Koalicja na Rzecz Gospodarki Obiegu Zamkniętego Reconomy, Gospodarka obiegu zamkniętego. Biznes i konsument na ścieżce zmiany, Warszawa 2017, s. 26.

${ }^{13}$ Koalicja na Rzecz Gospodarki Obiegu Zamkniętego Reconomy, W kierunku gospodarki obiegu zamkniętego. Wyzwania i szanse, Warszawa 2016, s. 35.

${ }^{14}$ Deloitte Sustainability Consulting Central Europe, Gospodarka o obiegu zamkniętym. Jak wyzwolić potencjał z planowanych zmian, Warszawa 2016, s. 8.

${ }^{15}$ Ellen MacArthur Foundation, Ku gospodarce o obiegu zamkniętym: biznesowe uzasadnienie przyspieszonej zmiany, s. 7-8, https://www.ellenmacarthurfoundation.org/assets/downloads/ PL-Towards-a-Circular-Economy-Business-Rationale-for-an-Accelerated-Transition-v.1.5.1.pdf [dostęp: 1.10.2018]. 
1. Odpady są „wyprojektowywane”. Do celów gospodarki o obiegu zamkniętym należy systemowa eliminacja odpadów. Materiały techniczne (polimery, stopy i inne wytwory działalności człowieka) powinny być zaprojektowane w taki sposób, aby możliwe było ich odzyskanie, odnowienie i ulepszenie. Pozwoli to zmniejszyć nakłady energii oraz zmaksymalizować poziom zachowania wartości (zarówno pod względem ekonomicznym, jak i zasobowym).

2. Różnorodność tworzy siłę. System gospodarczy można przyrównać do ekosystemu, w którym to bioróżnorodność warunkuje przetrwanie zmian środowiskowych. W gospodarce, na podobnej zasadzie, musi zostać zbilansowany rozmiar poszczególnych sektorów. Stwarza się w ten sposób warunki rozwoju w długiej perspektywie.

3. Gospodarkę zasila energia ze źródeł odnawialnych. Ponieważ gospodarka obiegu zamkniętego dąży do uniezależnienia od wykorzystania zasobów oraz zwiększenia odporności systemu gospodarczego, energia wykorzystywana do jej napędzenia powinna ze swej natury być odnawialna. Szansa na urzeczywistnienie tej idei będzie rosła w miarę zmniejszającego się zapotrzebowania na energię.

4. Istotne jest myślenie systemowe. Świat składa się z wielu elementów (m.in. firmy, ludzie, rośliny), które funkcjonują w ramach złożonych systemów. Poszczególne części tych systemów są ze sobą powiązane, niekiedy w zaskakujący sposób. O efektywności zmian w kierunku gospodarki o obiegu zamkniętym decyduje uwzględnienie wszystkich tych zależności oraz wynikających z nich konsekwencji.

5. Ceny bądź inne mechanizmy informacji zwrotnej odzwierciedlają rzeczywiste koszty. W gospodarce obiegu zamkniętego ceny pełnią funkcję wskaźników. Ich efektywność zależy od zdolności do odzwierciedlenia wszelkich kosztów, łącznie z kosztami negatywnych efektów zewnętrznych. Brak przejrzystości w tym zakresie może działać hamująco na proces wdrażania gospodarki cyrkulacyjnej.

$\mathrm{Na}$ poziomie operacyjnym gospodarka obiegu zamkniętego opiera się na koncepcji 3R, a także na poszerzających jej zakres modyfikacjach, takich jak 4R, $4 \mathrm{RV}+\mathrm{OGES}$ czy $5 \mathrm{R}$.

Formułę 3R tworzą hasła: ograniczać, ponownie zastosować, poddawać recyklingowi. Motywem przewodnim tej koncepcji jest zwiększenie udziału surowców wtórnych używanych do produkcji oraz ograniczenie wykorzystania energii i zasobów naturalnych. Na jej bazie opracowano koncepcję 4R (wydłużać okres przydatności, naprawiać, odnawiać, poddawać recyklingowi), kanadyjską formułę 4RV + OGES (zmniejszać, ponownie wykorzystywać, recyklingować, regenerować, waloryzować + zerowa emisja gazów cieplarnianych) oraz szwajcarskie 5R (zmniejszać, naprawiać, ponownie wykorzystywać, recyklingować, wymyślać 

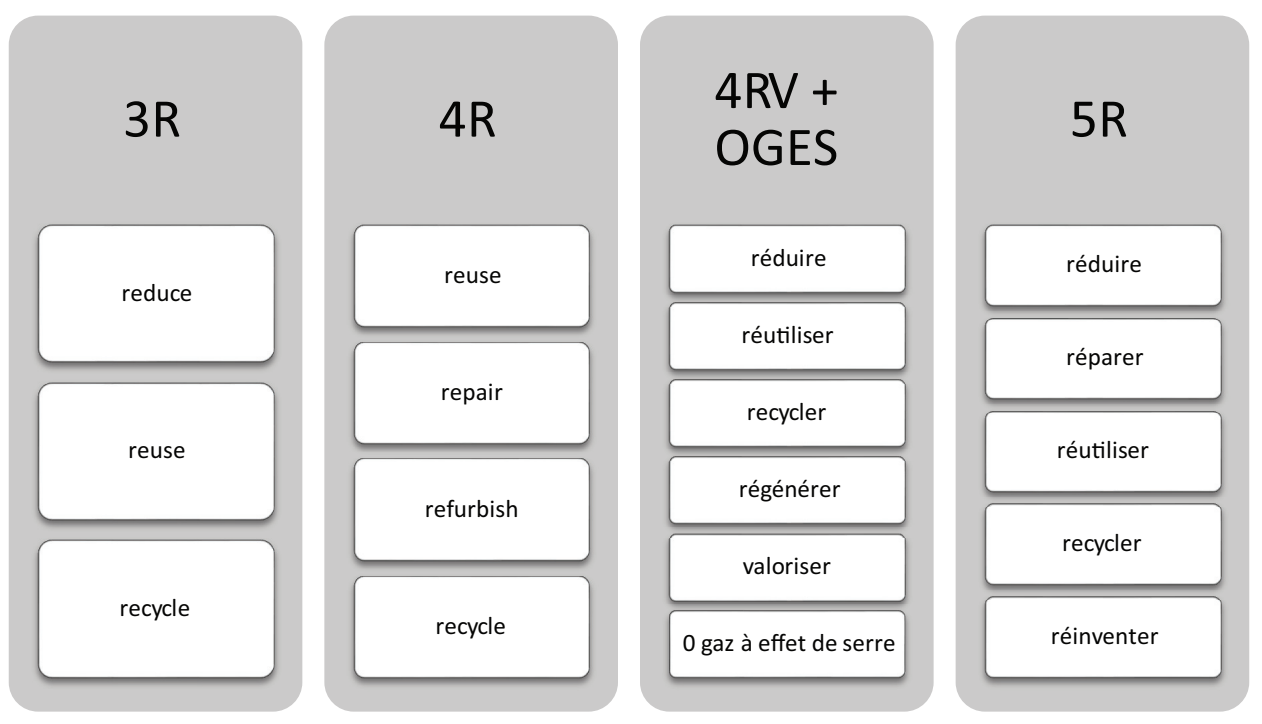

Rysunek 1. Koncepcje w ramach GOZ

Źródło: opracowanie własne na podstawie P. Szyja, Istota, zakres i praktyka kształtowania gospodarki okrężnej, „Prace Naukowe Uniwersytetu Ekonomicznego we Wrocławiu” 2016, nr 453, s. 134; M. Raftowicz-Filipkiewicz, Ekonomia cyrkularna - wyzwanie i konieczność zrównoważonego rozwoju, „Studia i Prace Wydziału Nauk Ekonomicznych i Zarządzania Uniwersytetu Szczecińskiego" 2015, t. 2, nr 40, s. 149-150.

od nowa $)^{16}$. Ta wieloformułowość wskazuje, że ideę gospodarki obiegu zamkniętego powinna cechować pewna elastyczność, aby możliwe było wprowadzanie odpowiednich modyfikacji, uwzględniające uwarunkowania ekonomiczne, polityczne i kulturowe, a także specyficzne potrzeby, oczekiwania oraz możliwości ${ }^{17}$.

\section{Przedsiębiorstwa w gospodarce obiegu zamkniętego}

Dyskusje wokół gospodarki o obiegu zamkniętym toczą się na całym świecie, stanowi ona obecnie jeden z najważniejszych tematów w biznesie. Grupa liderów biznesu podejmujących długofalowe działania na rzecz tej koncepcji staje się coraz liczniejsza. Powstają innowacyjne produkty i usługi, uzasadnione nie tylko ekonomicznie, lecz pożyteczne również z punktu widzenia społeczeństwa

${ }^{16}$ P. Szyja, Istota, zakres i praktyka ksztaltowania gospodarki okrężnej, „Prace Naukowe Uniwersytetu Ekonomicznego we Wrocławiu” 2016, nr 453, s. 134; M. Raftowicz-Filipkiewicz, Ekonomia cyrkularna - wyzwanie i konieczność zrównoważonego rozwoju, „Studia i Prace Wydziału Nauk Ekonomicznych i Zarządzania Uniwersytetu Szczecińskiego" 2015, t. 2, nr 40, s. 149-150.

${ }_{17}$ M. Raftowicz-Filipkiewicz, Ekonomia cyrkularna ..., s. 150. 
i ochrony środowiska. W dodatku radykalnie zmienia się sposób funkcjonowania przedsiębiorstw, wprowadza się nowe modele biznesowe, a także odmienne wskaźniki i wymiary konkurencyjności ${ }^{18}$. Tabela 1 prezentuje modele i strategie stosowane przez firmy wdrażające rozwiązania GOZ.

Tabela 1. Modele biznesowe i strategie obiegu zamkniętego

\begin{tabular}{|c|c|}
\hline Modele biznesowe & Strategie \\
\hline \multirow{6}{*}{$\begin{array}{l}\text { 1. Łańcuch dostaw obiegu zamkniętego } \\
\text { 2. Odzyskiwanie i recykling } \\
\text { 3. Wydłużenie życia produktu } \\
\text { 4. Platforma współdzielenia } \\
\text { 5. Produkt jako usługa }\end{array}$} & Przyspieszające wzrost firmy \\
\hline & $\begin{array}{l}\text { 1. Kreowanie dodatkowej wartości w istniejących } \\
\text { produktach i usługach } \\
\text { 2. Podnoszenie innowacyjności produktów i usług } \\
\text { 3. Zmniejszanie kosztów operacyjnych }\end{array}$ \\
\hline & Wzmacniające konkurencyjność \\
\hline & $\begin{array}{l}\text { 4. Poprawa relacji z klientami i pracownikami } \\
\text { 5. Odróżnienie się od konkurencji } \\
\text { 6. Dostosowanie strategii firmy do misji }\end{array}$ \\
\hline & Zmniejszające ryzyko \\
\hline & $\begin{array}{l}\text { 7. Dostosowanie modelu biznesowego do wartości } \\
\text { łańcucha dostaw } \\
\text { 8. Zmniejszenie ryzyka linearnej ekspozycji }\end{array}$ \\
\hline
\end{tabular}

Źródło: opracowanie własne na podstawie Koalicja na Rzecz Gospodarki Obiegu Zamkniętego Reconomy, W kierunku gospodarki obiegu zamkniętego. Wyzwania i szanse, Warszawa 2016, s. 7-8; Koalicja na Rzecz Gospodarki Obiegu Zamkniętego Reconomy, Gospodarka obiegu zamkniętego. Biznes i konsument na ścieżce zmiany, Warszawa 2017, s. 46.

Przedstawione w tabeli 1 modele biznesowe wyodrębniono na podstawie analizy ponad 120 przedsiębiorstw, które wyróżniały się zwiększeniem produktywności zasobów osiągniętym za pomocą wdrażanych innowacji ${ }^{19}$. Łańcuch dostaw obiegu zamkniętego sprowadza się do wykorzystywania odnawialnej energii oraz materiałów biodegradowalnych lub nadających się do recyklingu. Istotę modelu ukierunkowanego na odzyskiwanie i recykling stanowi natomiast tworzenie systemów konsumpcji i produkcji, w których wykorzystuje się do nowych zastosowań wszystko, co uważano dotąd za odpady. $Z$ kolei wydłużenie życia produktu ma na celu jego naprawianie, ulepszanie, przetwarzanie czy remarketing (odsprzedaż). Platformy współdzielenia umożliwiają konsumentom dzielenie się, wynajmowanie, zamianę lub wypożyczanie rzadko wykorzystywanych przez nich dóbr, w modelu ,produkt jako usługa” zaś konsumenci

${ }^{18}$ Instytut Innowacyjna Gospodarka, W kierunku gospodarki cyrkularnej. Rekomendacje rozwoju i implementacji praktycznych rozwiazań dla biznesu, s. 4, http://www.r2piproject.eu/wp-content/uploads/2018/04/raport_w_kierunku_gospodarki_cyrkularnej-1.pdf [dostęp: 5.10.2018].

${ }_{19}$ Koalicja na Rzecz Gospodarki Obiegu Zamkniętego Reconomy, W kierunku..., s. 7. 
płacą za wynajem lub użytkowanie produktu, co skłania firmy do troski przede wszystkim o jego jakość i wydajność ${ }^{20}$.

Obok wymienionych modeli wyróżnia się także strategie wpisujące się w założenia gospodarki obiegu zamkniętego. Światowa Rada Biznesu na Rzecz Zrównoważonego Rozwoju wskazała je na podstawie serii wywiadów przeprowadzonych wśród przedsiębiorstw. Wzrost firmy mogą przyspieszyć strategie nastawione na naprawianie i odnawianie produktów lub zastępowanie ich usługami (kreowanie dodatkowej wartości w istniejących produktach i usługach), nadanie wartości produktom przez wprowadzenie zmian w projekcie lub funkcjonalności (podnoszenie innowacyjności produktów i usług) oraz odpowiednie i jak najbardziej efektywne korzystanie z posiadanych zasobów, co prowadzi do ograniczania kosztów operacyjnych. Aby zwiększyć swą konkurencyjność, przedsiębiorstwa powinny zadbać o nawiązywanie długoterminowych relacji z klientami i pracownikami, a także wykorzystać możliwości, jakie oferuje GOZ do odróżnienia się od pozostałych firm (np. zabezpieczając niszowy rynek lub stając się liderem zmian). Przewagę konkurencyjną może tworzyć również spójność przekazu oraz dołączony do produktów etos (dostosowanie strategii do misji). Natomiast przejawy strategii zmniejszających ryzyko to m.in. strategiczne partnerstwa czy zarządzanie ryzykiem liniowym dzięki uwzględnieniu elastyczności w planowaniu strategicznym (dostosowanie modelu biznesowego do wartości łańcucha dostaw), jak również unikanie zagrożenia niedoboru surowców przez odzyskiwanie zasobów i ich ponowne wykorzystanie w procesie produkcji (zmniejszenie ryzyka linearnej ekspozycji) ${ }^{21}$.

W opracowaniach dotyczących gospodarki o obiegu zamkniętym podkreśla się, że może ona stanowić ogromną szansę dla sektora biznesu. Wymienia się w tym kontekście następujące korzyści:

- wykorzystując modele biznesowe GOZ, firmy są w stanie wygenerować dodatkowe zyski na poziomie 4,5 biliona dolarów do $2030 \mathrm{roku}^{22}$,

- przejście na GOZ w sektorach transportu, żywności i sektorze budowlanym pozwoliłoby na oszczędności podstawowych nakładów na surowce rzędu 600 milionów euro rocznie w UE-27 do 2030 roku $^{23}$,

- unijne przedsiębiorstwa, wdrażając rozwiązania GOZ (m.in. zapobieganie powstawaniu odpadów, przeprojektowanie produktów), mogłyby zaoszczędzić od 245 do 604 miliardów euro, co stanowi 3-8\% ich rocznego obrotu ${ }^{24}$,

${ }^{20}$ E. Jastrzębska, Gospodarka o obiegu zamkniętym - nowa idea czy stare podejście? Dobre praktyki spotecznie odpowiedzialnych przedsiębiorstw, „Prace Naukowe Uniwersytetu Ekonomicznego we Wrocławiu" 2017, nr 491, s. 228.

${ }^{21}$ Koalicja na Rzecz Gospodarki Obiegu Zamkniętego Reconomy, Gospodarka obiegu..., s. $46-49$.

${ }^{22}$ Koalicja na Rzecz Gospodarki Obiegu Zamkniętego Reconomy, W kierunku..., s. 6.

${ }^{23}$ Koalicja na Rzecz Gospodarki Obiegu Zamkniętego Reconomy, Gospodarka obiegu..., s. 26.

${ }^{24}$ European Environment Agency, Circular economy in Europe. Developing the knowledge base, Publications Office of the European Union, Luxembourg 2016, s. 13. 
- gospodarka obiegu zamkniętego sprzyja większemu bezpieczeństwu dostaw,

- w warunkach gospodarki cyrkulacyjnej wykreowany zostanie popyt na nowe usługi biznesowe (np. logistyka zbiórki i odzysku, platformy sprzedaży i remarketingu $)^{25}$.

Warto zatem zwrócić uwagę, że przedsiębiorstwa, które z sukcesem zaimplementują rozwiązania, modele i strategie charakterystyczne dla gospodarki obiegu zamkniętego, mają szanse zyskać wyraźną przewagę. Ale też firmy te będą musiały sprostać wielu wyzwaniom, jakie wiążą się z tak poważną zmianą. Przejście do gospodarki cyrkulacyjnej przekłada się bowiem na zupełnie nowy charakter relacji firma-klient.

\section{Wyzwania związane z wdrażaniem założeń GOZ przez przedsiębiorstwa}

Najważniejsze wyzwania, przed którymi stoi sektor biznesu, można podzielić na grupy, wykorzystując schemat ReSOLVE (od angielskich słów: Regenerate, Share, Optimise, Loop, Virtualise, Exchange). Wyodrębnia on sześć głównych obszarów działań sprzyjających przechodzeniu na gospodarkę obiegu zamkniętego. Wyzwania przypisano także do kolejnych etapów cyklu życia produktu (tab. 2).

Tabela 2. Wyzwania dla przedsiębiorstw

\begin{tabular}{|c|c|}
\hline Model ReSOLVE & Cykl życia produktu \\
\hline 1. Regeneracja & 1. Etap projektowania \\
\hline $\begin{array}{l}\text { - Przechodzenie na odnawialne materiały } \\
\text { i źródła energii } \\
\text { - Przywracanie, utrzymanie i odbudowa stanu } \\
\text { ekosystemów } \\
\text { - Zwrot odzyskanych zasobów biologicznych } \\
\text { do biosfery }\end{array}$ & $\begin{array}{l}\text { - Ukierunkowanie na trwałość produktów } \\
\text { - Dbałość o wykonanie produktów, by nie } \\
\text { ulegały uszkodzeniom } \\
\text { - Modułowy charakter produktów } \\
\text { - Tworzenie zasobooszczędnych } \\
\text { i efektywnych energetycznie produktów }\end{array}$ \\
\hline 2. Współdzielenie & 2. Etap wyboru materiałów \\
\hline $\begin{array}{l}\text { - Współużytkowanie (m.in. samochodów, } \\
\text { urządzeń, pomieszczeń) } \\
\text { - Ponowne wykorzystanie (second hand) } \\
\text { - Wydłużanie cyklu życia produktów dzięki } \\
\text { konserwacji, możliwości ulepszania, } \\
\text { zwiększonej wytrzymałości }\end{array}$ & $\begin{array}{l}\text { - Używanie materiałów z odzysku zamiast } \\
\text { nowych zasobów } \\
\text { - Wykorzystywanie produktów ubocznych } \\
\text { - Zapewnienie wysokiej jakości odpadów } \\
\text { przetworzonych w procesie recyklingu } \\
\text { - Monitorowanie i zwiększanie wydajności } \\
\text { zasobów }\end{array}$ \\
\hline
\end{tabular}

${ }^{25}$ Ellen MacArthur Foundation, Ku gospodarce o obiegu zamkniętym..., s. 14. 


\begin{tabular}{|c|c|}
\hline 3. Optymalizacja & 3. Etap produkcji \\
\hline $\begin{array}{l}\text { - Zwiększanie wydajności produktów } \\
\text { - Eliminacja odpadów w łańcuchu produkcji } \\
\text { i dostaw } \\
\text { - Produkcja na życzenie } \\
\text { - Wykorzystanie dużych zbiorów danych, } \\
\text { automatyzacji, teledetekcji i zdalnych } \\
\text { układów sterowania }\end{array}$ & $\begin{array}{l}\text { - Identyfikacja wartościowych odpadów } \\
\text { - Udoskonalanie i modernizacja produktów } \\
\text { - Poprawa ekoefektywności } \\
\text { i ekoinnowacyjności }\end{array}$ \\
\hline 4. Zapętlanie & 4. Etap użytkowania \\
\hline $\begin{aligned} \text { - Ponowne użycie produktów lub } \\
\text { komponentów } \\
\text { - Recykling, Recykling } 2.0 \\
\text { - Upcykling } \\
\text { - Fermentacja beztlenowa } \\
\text { - Ekstrakcja materiałów biochemicznych } \\
\text { z odpadów organicznych }\end{aligned}$ & $\begin{array}{l}\text { - Świadczenie usług opartych na oferowanych } \\
\text { produktach } \\
\text { - Oszacowanie kosztów tych usług oraz } \\
\text { sposobów ich finansowania }\end{array}$ \\
\hline 5. Wirtualizacja & 5. Etap ponownego użycia \\
\hline $\begin{array}{l}\text { - Bezpośrednia dematerializacja (np. książek, } \\
\text { płyt CD i DVD) } \\
\text { - Pośrednia dematerializacja (np. zakupy } \\
\text { online) }\end{array}$ & \multirow{3}{*}{$\begin{array}{l}\text { - Wyodrębnienie surowców, które warto } \\
\text { odzyskać } \\
\text { - Nowy cykl życia i drugi obieg: nadanie } \\
\text { produktom drugiego życia } \\
\text { - Stworzenie systemu dla ponownego użycia } \\
\text { i napraw }\end{array}$} \\
\hline 6. Wymiana & \\
\hline $\begin{array}{l}\text { - Wykorzystanie nowych technologii } \\
\text { (np. druku 3D) } \\
\text { - Wykorzystanie nowych, bardziej } \\
\text { zaawansowanych materiałów } \\
\text { - Wybór nowych produktów i usług } \\
\text { (np. transportu multimodalnego) }\end{array}$ & \\
\hline
\end{tabular}

Źródło: opracowanie własne na podstawie: Ellen MacArthur Foundation, Ku gospodarce o obiegu zamkniętym: biznesowe uzasadnienie przyspieszonej zmiany, s. 9, https://www. ellenmacarthurfoundation.org/assets/downloads/PL-Towards-a-Circular-Economy-BusinessRationale-for-an-Accelerated-Transition-v.1.5.1.pdf [dostęp: 5.10.2018]; Koalicja na Rzecz Gospodarki Obiegu Zamkniętego Reconomy, W kierunku gospodarki obiegu zamkniętego. Wyzwania i szanse, Warszawa 2016, s. 37; Koalicja na Rzecz Gospodarki Obiegu Zamkniętego Reconomy, Gospodarka obiegu zamkniętego. Biznes i konsument na ścieżce zmiany, Warszawa

2017, s. 50; Instytut Gospodarki o Obiegu Zamkniętym, Polska droga do gospodarki o obiegu zamkniętym. Opis sytuacji i rekomendacje, s. 21-73, http://igoz.org/wp/wp-content/ uploads/2017/04/Polska_droga_do_GOZ_IGOZ.pdf [dostęp: 5.10.2018].

Wskazane powyżej wyzwania dotyczą wszystkich obszarów działalności przedsiębiorstwa oraz etapów cyklu życia produktu. Gospodarkę obiegu zamkniętego określa się mianem największej rewolucji od czasów pierwszej rewolucji przemysłowej, co może okazać się szczególnie trafne w odniesieniu do sektora biznesu. Dlatego istotne jest odpowiednie przygotowanie się do przejścia na 
gospodarkę o obiegu zamkniętym przez uwzględnienie tego procesu zarówno w zamierzeniach strategicznych, jak i planach taktycznych i operacyjnych.

Przykłady konkretnych rozwiązań w postaci schematów procesu wdrażania założeń gospodarki obiegu zamkniętego zostały zaproponowane przez Deloitte oraz Światową Radę Biznesu na Rzecz Zrównoważonego Rozwoju (World Business Council for Sustainable Development - WBCSD).
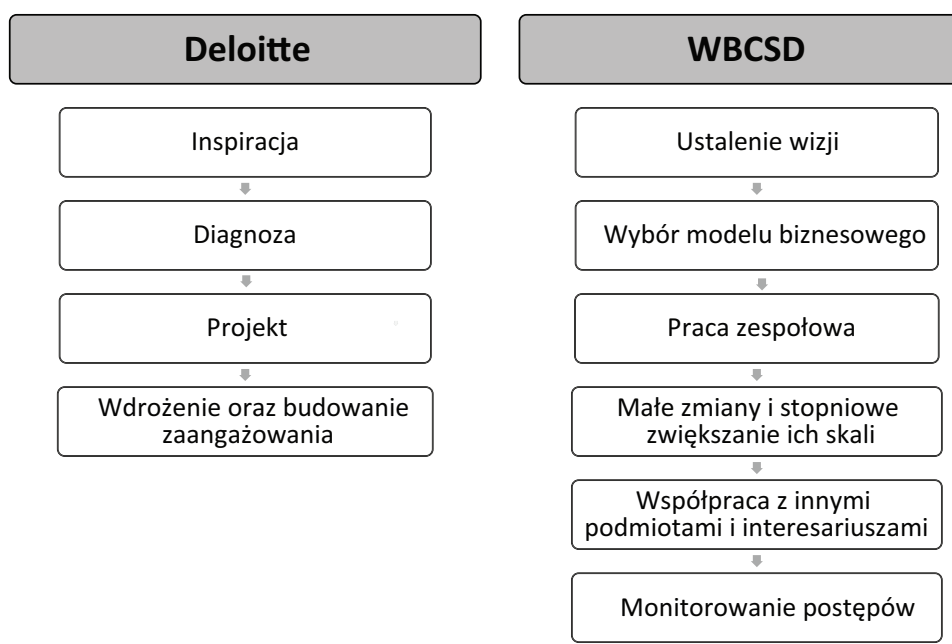

Rysunek 2. Proces wdrażania założeń GOZ przez przedsiębiorstwa

Źródło: opracowanie własne na podstawie Deloitte Sustainability Consulting Central Europe, Gospodarka o obiegu zamkniętym. Jak wyzwolić potencjał z planowanych zmian, Warszawa 2016, s. 25; World Business Council for Sustainable Development, CEO Guide to the Circular Economy, s. 18, https://docs.wbcsd.org/2017/06/CEO_Guide_to_CE.pdf [dostęp: 5.10.2018].

Pierwszym krokiem do wprowadzania przez przedsiębiorstwo rozwiązań w zakresie GOZ według Deloitte jest inspiracja (jej źródłem mogą być np. rozmowy i sesje dialogowe, dedykowane prezentacje czy warsztaty). Na tym etapie należy zidentyfikować potrzeby firmy. Następna jest diagnoza, czyli ocena możliwości wdrożenia zmian. Stanowi ona podstawę przygotowania projektu nowego modelu biznesowego, który odpowiada założeniom gospodarki cyrkulacyjnej. Ostatnim etapem jest wdrożenie opracowanego modelu oraz budowanie zaangażowania wśród klientów ${ }^{26}$.

Zgodnie ze schematem przedstawionym przez WBCSD proces implementacji założeń GOZ rozpoczyna się od określenia wizji przedsiębiorstwa. W tym celu konieczne jest stworzenie nadrzędnych reguł, a także zmian w zakresie ładu korporacyjnego. Ponadto wyodrębnia się szanse i cele do osiągnięcia.

${ }^{26}$ Deloitte Sustainability Consulting Central Europe, Gospodarka o obiegu zamkniętym..., s. 25. 
Kolejnym krokiem jest wybór modelu biznesowego, umożliwiającego transformację w kierunku gospodarki o obiegu zamkniętym. Sukces we wdrażaniu założeń GOZ zależy od współpracy między poszczególnymi działami firmy (m.in. B+R, zaopatrzenie, łańcuch dostaw, produkcja, marketing). WBCSD proponuje rozpocząc od pilotażowych programów, które z czasem mogą przełożyć się na długoterminowe strategie. Istotne jest podjęcie działań zmierzających do zwiększenia skali wprowadzanych zmian. Zaleca się także nawiązanie współpracy z innymi firmami oraz interesariuszami. Cały proces należy ocenić, posługując się wskaźnikami o charakterze finansowym, środowiskowym oraz społecznym ${ }^{27}$.

\section{Podsumowanie i wnioski}

Idea gospodarki o obiegu zamkniętym zyskała w ostatnim czasie dużą popularność, czego przejawem jest m.in. wdrażanie rozwiązań wpisujących się w jej założenia przez przedsiębiorstwa, głównie korporacje międzynarodowe i start-upy. Możliwości, jakie niesie ze sobą GOZ, sprawiają, że firmy, które dokonają efektywnej transformacji swoich modeli biznesowych, mogą oczekiwać osiągnięcia wymiernych korzyści. Wiąże się to jednak z szeregiem wyzwań, gdyż implementacja rozwiązań z zakresu gospodarki obiegu zamkniętego w długiej perspektywie wymaga głębokich zmian w najważniejszych obszarach działalności przedsiębiorstwa.

Wśród największych wyzwań wymienić można: wprowadzenie znaczących modyfikacji w projektach produktów lub zaprojektowanie ich od nowa, wdrożenie nowych technologii (np. druk 3D, analiza big data), zwiększenie wydajności i trwałości oferowanych produktów, przechodzenie na odnawialne źródła energii i materiały, identyfikacja wartościowych odpadów i ich ponowne wykorzystanie. Aby im sprostać, konieczne jest podejście systemowe, ukierunkowane na wzajemne powiązania występujące w organizacji. Pomocne mogą okazać się przykładowe schematy dotyczące wdrażania zmian, jednak należy podkreślić, że nie istnieje uniwersalny sposób gwarantujący sukces wszystkim firmom. Proces ten powinien być dostosowany do konkretnego przedsiębiorstwa, ze szczególnym uwzględnieniem jego specyficznych cech, możliwości i ograniczeń.

${ }^{27}$ World Business Council for Sustainable Development, CEO Guide to the Circular Econo$m y$, s.18, https://docs.wbcsd.org/2017/06/CEO_Guide_to_CE.pdf [dostęp: 5.10.2018]. 


\section{Bibliografia}

Brears R.C., Natural Resource Management and the Circular Economy, Palgrave Macmillan, New York 2018.

Deloitte Sustainability Consulting Central Europe, Gospodarka o obiegu zamkniętym. Jak wyzwolić potencjat z planowanych zmian, Warszawa 2016.

Ellen MacArthur Foundation, Ku gospodarce o obiegu zamkniętym: biznesowe uzasadnienie przyspieszonej zmiany, https://www.ellenmacarthurfoundation.org/assets/downloads/PL-Towards-a-Circular-Economy-Business-Rationale-for-an-Accelerated-Transition-v.1.5.1.pdf [dostęp: 1.10.2018].

European Environment Agency, Circular economy in Europe. Developing the knowledge base, Publications Office of the European Union, Luxembourg 2016.

Instytut Gospodarki o Obiegu Zamkniętym, Polska droga do gospodarki o obiegu zamkniętym. Opis sytuacji i rekomendacje, http://igoz.org/wp/wp-content/uploads/2017/04/Polska_droga_ do_GOZ_IGOZ.pdf [dostęp: 5.10.2018].

Instytut Innowacyjna Gospodarka, $W$ kierunku gospodarki cyrkularnej. Rekomendacje rozwoju i implementacji praktycznych rozwiazań dla biznesu, http:/www.r2piproject.eu/wp-content/ uploads/2018/04/raport_w_kierunku_gospodarki_cyrkularnej-1.pdf [dostęp: 5.10.2018].

Jastrzębska E., Gospodarka o obiegu zamkniętym - nowa idea czy stare podejście? Dobre praktyki społecznie odpowiedzialnych przedsiębiorstw, „Prace Naukowe Uniwersytetu Ekonomicznego we Wrocławiu" 2017, nr 491.

Koalicja na Rzecz Gospodarki Obiegu Zamkniętego Reconomy, Gospodarka obiegu zamkniętego. Biznes i konsument na ścieżce zmiany, Warszawa 2017.

Koalicja na Rzecz Gospodarki Obiegu Zamkniętego Reconomy, W kierunku gospodarki obiegu zamkniętego. Wyzwania i szanse, Warszawa 2016.

Komisja Europejska, Zamknięcie obiegu - plan działań UE dotyczący gospodarki o obiegu zamkniętym, Komunikat Komisji do Parlamentu Europejskiego, Rady, Europejskiego Komitetu Ekonomiczno-Społecznego i Komitetu Regionów, COM(2015) 614 final, Bruksela 2015.

Krausmann F., Gingrich S., Eisenmenger N., Erb K.H., Haberl H., Fischer-Kowalski M., Growth in global material use, GDP and population during the 20th century, „Ecological Economics” 2009, Vol. 68, No. 10.

Lacy P., Rutqvist J., Waste to wealth. Creating advantage in a circular economy, Palgrave Macmillan, New York 2015.

Mao J., Liu Ch., Pei Y., Xu L., Circular economy and sustainable development enterprises, Springer Nature, Singapore 2018.

Raftowicz-Filipkiewicz M., Ekonomia cyrkularna - wyzwanie i konieczność zrównoważonego rozwoju, „Studia i Prace Wydziału Nauk Ekonomicznych i Zarządzania Uniwersytetu Szczecińskiego" 2015, t. 2, nr 40.

Rokicka E., Woźniak W., W kierunku zrównoważonego rozwoju. Koncepcje, interpretacje, konteksty, Katedra Socjologii Ogólnej, Wydział Ekonomiczno-Socjologiczny, Uniwersytet Łódzki, Łódź 2016.

Rutkowska-Podołowska M., Popławski Ł., Współczesny kapitalizm a ochrona środowiska, „Studia i Prace Wydziału Nauk Ekonomicznych i Zarządzania Uniwersytetu Szczecińskiego” 2014, t. 2, nr 41.

Szyja P., Istota, zakres i praktyka kształtowania gospodarki okrężnej, „Prace Naukowe Uniwersytetu Ekonomicznego we Wrocławiu” 2016, nr 453.

World Business Council for Sustainable Development, CEO Guide to the Circular Economy, https:// docs.wbcsd.org/2017/06/CEO_Guide_to_CE.pdf [dostęp: 5.10.2018]. 


\section{Streszczenie}

Gospodarka o obiegu zamkniętym dąży do oddzielenia wzrostu gospodarczego od zużycia zasobów i wpływu na środowisko. Dla przedsiębiorstw stanowi źródło zarówno potencjalnych korzyści, jak i poważnych wyzwań. Celem artykułu jest wyodrębnienie wyzwań, z którymi muszą zmierzyć się firmy wdrażające założenia tej koncepcji. Przedstawiono także charakterystyczne dla gospodarki obiegu zamkniętego modele biznesowe i strategie. Niniejszy artykuł ma charakter teoretyczny.

Słowa kluczowe: gospodarka o obiegu zamkniętym, środowisko, przedsiębiorstwa Numer klasyfikacji JEL: M14, O44, Q50 